\title{
ANALYSIS OF THE IMMUNOGENICITY AND STABILITY OF A PORCINE PULMONARY SURFACTANT PREPARATION ADMINISTERED IN RABBITS
}

\author{
Alexander R. Preciosoa, Paula P.O Sakae ${ }^{a}$, Renata S. Mascarettia, Flávia S. \\ Kubrusly $^{\mathrm{b}}$, Vera C. B. Cainelli Gebara ${ }^{\mathrm{b}}$, Dmitri Iourtov ${ }^{\mathrm{b}}$, Celso M. Rebello ${ }^{\mathrm{b}}$, \\ Flávio A. C. Vaz , and Isaías Raw
}

Precioso AR, Sakae PPO, Mascaretti RS, Kubrusly FS, Gebara VCBC, Iourtov D et al. Analysis of the immunogenicity and stability of a porcine pulmonary surfactant preparation administered in rabbits. Clinics. 2006;61(2):153-60.

PURPOSE: To study the immunogenicity and the stability of the porcine pulmonary surfactant preparation produced by the Instituto Butantan.

METHOD: Immunogenicity assay: Sixteen New-Zealand-White rabbits (1000 g body weight) were divided into 4 study groups. Each group was assigned to receive either a) Butantan surfactant, b) Survanta ${ }^{\circledR}$ (Abbott Laboratories), c) Curosurf ${ }^{\circledast}$ (Farmalab Chiesi), or d) no surfactant. The surfactants were administered intratracheally, and the animals were collected immediately before and 60 and 180 days after surfactant administration. Sera were assayed for the presence of antisurfactant antibodies by enzymelinked immunosorbent assay (ELISA). Stability assay: The Butantan surfactant used in this assay had been stored for one year in the refrigerator $\left(4\right.$ to $\left.8^{\circ} \mathrm{C}\right)$ and its stability was evaluated in distinct assay conditions using a premature rabbit model.

RESULTS: Immunogenicity assay: None of the surfactants analyzed triggered antibody immune responses against their components in any of the animals. Stability assay: The results of this study demonstrate that Butantan surfactant was as effective as Curosurf when both were submitted to the adverse circumstance of short- and long-term storage at room temperature. A similar level of efficacy for the Butantan surfactant, as compared to Curosurf was demonstrated by the pulmonary dynamic compliance, ventilatory pressure, and pressure-volume curve results.

CONCLUSION: The results of our study demonstrate that Butantan surfactant may be a suitable alternative for surfactant replacement therapy.

KEYWORDS: Porcine pulmonary surfactant. Immunogenicity. Stability. Animal model.

\section{INTRODUCTION}

The Butantan Institute (Brazil) has produced a porcine pulmonary surfactant preparation (Butantan surfactant) that is obtained by organic extraction coupled with adsorption on a cellulose derivative. ${ }^{1,2}$ The major advantage of this preparation is the avoidance of large-volume, high-speed

a Pediatrics Department, São Paulo University Medical School - São Paulo/ SP, Brazil.

${ }^{b}$ Biotechnology Center, Butantan Institute - São Paulo/SP, Brzail.

Email: aprecioso@uol.com.br

Received for publication on November 11, 2005.

Accepted for publication on February 08, 2006. centrifugation, thus making it feasible to produce in a lowcost plant. This surfactant, as happens with all solvent-extracted mammalian surfactants, is composed mainly of phospholipids with 2 hydrophobic polypeptides, SP-B and SP-C, both of which are necessary for optimal surfactant function for treatment of neonatal respiratory distress syndrome. This surfactant contains $76 \%$ phosphatidylcholine, $6 \%$ to $8 \%$ phosphatidyllethanolamine, $6 \%$ phosphatidylinositol + phosphatidylserine, and $4 \%$ to $6 \%$ sphingomyelin; $30 \%$ to $35 \%$ of the phosphatidylcholine is dipalmitoyl phosphatidylcholine. The total content of protein is $5.6 \%$ of the total composition of the surfactant. 
The in vivo evaluation of Butantan surfactant compared to other commercially available surfactants using the preterm rabbit model showed similar pulmonary effects, improving pulmonary functions as assessed by the decrease of the ventilatory pressure and the increase of the dynamic compliance. $^{3}$

In order to demonstrate the efficacy and safety of this surfactant in premature infants, it was first necessary to study its immunogenicity in an adult rabbit model. The need for studying immunogenicity is based on the possibility that the introduction of the porcine surfactant proteins into the airway of premature infants might provide an antigenic stimulus with resultant immunological response against those proteins. ${ }^{4-8}$ Furthermore, it was necessary to evaluate the stability of this surfactant submitted to adverse storage conditions ${ }^{9}$ in order to determine the expiration date; this was done by testing efficacy in a premature rabbit model.

\section{MATERIALS AND METHODS}

The protocol was approved by the local ethics committee for animal experiments.

\section{Immunogenicity assay}

Sixteen New-Zealand-White rabbits (1000 g body weight) were divided into groups of 4 animals. Each group was assigned to receive either a) Butantan surfactant; b) Survanta ${ }^{\circledR}$ Abbott Laboratories); c) Curosurf ${ }^{\circledR}$ (Farmalab Chiesi); or d) no surfactant treatment. Each surfactant was administered intratracheally (dose: $100 \mathrm{mg} / \mathrm{kg}$ ), and the animals were collected immediately before and 60 and 180 days after surfactant administration. Sera were assayed for the presence of antisurfactant antibodies by enzyme-linked immunosorbent assay (ELISA). Plates (96-wells, flat bottom, Nunc Maxisorp Immunoplate) were coated overnight at $4^{\circ} \mathrm{C}$ with Butantan surfactant, Survanta, and Curosurf ( $1 \mathrm{mg}$ of protein/well) in $0.1 \mathrm{M}$ carbonate-bicarbonate buffer, $\mathrm{pH} 9.6$, overnight at $4^{\circ} \mathrm{C}$. Wells without antigen were used to control assay specificity. Plates were washed with PBS containing 0.05\% Tween-20 (PBS-T) and incubated overnight at $4{ }^{\circ} \mathrm{C}$ with a blocking solution $(10 \%$ fetal calf serum) to reduce nonspecific binding. Plates were washed again with PBS-T and incubated overnight at $4^{\circ} \mathrm{C}$ with serial dilutions of the sera (nondiluted, 1:10 to 1:1,000), in triplicate for each time point. Sera from the group receiving no surfactant treatment were used to control specificity. After washing the plates, an appropriate dilution of donkey antirabbit immunoglobulin horseradish-peroxidase conjugate (Sigma) was added. Plates were incubated for $2 \mathrm{~h}$ at room temperature, washed again, and a substrate buffer ( $0.2 \%$ O-phenylenediamine and $0.015 \% \mathrm{H}_{2} \mathrm{O}_{2}$ in citratephosphate buffer, $\mathrm{pH}$ 7.4) was added. The reaction was stopped with $4.5 \mathrm{M} \mathrm{H}_{2} \mathrm{SO}_{4}$ and the absorbance measured at $492 \mathrm{~nm}$ in a microplate reader. Results are reported as the mean absorbance \pm SD of triplicate wells. Absorbance values above 0.1 were considered positive. Statistical analysis of the data was performed by 1-way analysis of variance (ANOVA) and Tukey's multiple comparison test, considering $P<0.05$ as the significance level (GraphPad Prism, 2.0, 1995).

\section{Stability assay}

The Butantan surfactant used in this study was stored for 1 year in the refrigerator $\left(4^{\circ} \mathrm{C}\right.$ to $\left.8^{\circ} \mathrm{C}\right)$, and stability was evaluated in distinct assay conditions as follows: The Butantan surfactant used in this study were stored for 1 year in the refrigerator $\left(4^{\circ} \mathrm{C}\right.$ to $\left.8^{\circ} \mathrm{C}\right)$, and stability was evaluated for Butantan and Curosurf in distinct assay conditions as follows.

time point 0 : immediately after removal from the refrigerator and warmed to $37^{\circ} \mathrm{C}$ for 5 minutes;

time point 1: 24 hours after removal from refrigerator and kept at room temperature $\left(24^{\circ} \mathrm{C}\right)$ before being warmed to $37^{\circ} \mathrm{C}$ for 5 minutes;

time point 2: 30 days after removal from refrigerator and kept at $20^{\circ} \mathrm{C}$-water bath temperature before being warmed to $37^{\circ} \mathrm{C}$ for 5 minutes;

time point 3: 60 days after removal from refrigerator and kept at $20^{\circ} \mathrm{C}$-water bath temperature before warmed to $37^{\circ}$ $\mathrm{C}$ for 5 minutes;

time point 4: 90 days after removal from refrigerator and kept at $20^{\circ} \mathrm{C}$-water bath temperature before being warmed to $37^{\circ} \mathrm{C}$ for 5 minutes;

time point 5: 180 days after removal from refrigerator and kept at $20^{\circ} \mathrm{C}$-water bath temperature before being warmed to $37^{\circ} \mathrm{C}$ for 5 minutes;

Curosurf, used as the gold standard control, was within its valid expiration date and was stored according to the manufacture's instructions.

\section{Animal experiments}

\section{Birth and ventilation initiation}

Pregnant rabbits at 27 days of gestation were sedated with an intramuscular application of ketamine and acepromazine solution $(10 \mathrm{mg} / \mathrm{kg}$ and $0.1 \mathrm{mg} / \mathrm{kg})$, followed by spinal anesthesia with $2 \mathrm{~mL}$ of a solution 1:1 (vol:vol) of lidocaine at $2 \%$ and bupivacaine at $0.5 \%$. After laparotomy and hys- 
terotomy over a thermal mattress, the newborn rabbits were removed, and the membranes and the placentas were taken. The first premature rabbit removed from from the uterine horn of each pregnant mother received no surfactant treatment (prematurity control). The following premature rabbits were removed from the uterus, one by one, and alternately from the right or left side. After being dried and the weighed, each animal was anesthetized with intraperitoneal ketamineacepromazine $(10 \mathrm{mg} / \mathrm{kg}-0.1 \mathrm{mg} / \mathrm{kg})$ and submitted to tracheostomy with a metal cannula (internal diameter of $1 \mathrm{~mm}$ ). In strict accordance with this protocol, 94 New Zealand White premature rabbits were delivered and randomized into 2 groups according to the surfactant treatment: Butantan surfactant $(n=47)$ and Curosurf $(n=47)$. For each of the study time points, 7 to 8 animals were used for Butantan surfactant, 7 to 8 for Curosurf. The surfactant dose used in both groups and at all time points described above was $100 \mathrm{mg} / \mathrm{kg} / \mathrm{body}$ weight.Before the initiation of ventilation, endotracheal administration of surfactant was performed, followed by manual ventilation with a self-inflating bag for about $10 \mathrm{sec}$ onds. Afterwards, the animals received pancuronium $(20 \mu \mathrm{g})$ through the intraperitoneal route so that there would be no spontaneous respiration.

\section{Mechanical Ventilation}

Mechanical respiration was started (INTER 3 $3_{\text {- }}$ Intermed-São Paulo) using the respiratory rate (RR) of 60 cycles/min, and inspired oxygen concentration $\left(\mathrm{FiO}_{2}\right)$ of $21 \%$; peak inspiratory pressure (PIP) was adjusted to to acquire a tidal-volume of $8 \mathrm{ml} / \mathrm{kg},{ }^{10}$ and a positive end-expiratory (PEEP) of $0 \mathrm{~cm} \mathrm{H}_{2} \mathrm{O}$; inspiratory and expiratory times were 0.5 seconds; this controlled assisted ventilation protocol was maintained over a 15-minute period.

After the initiation of the ventilation, tidal-volume $\left(\mathrm{V}_{\mathrm{t}}\right)$ data, dynamic compliance (DC), and ventilatory pressure (VP) at 5, 10, and 15 minutes were determined. Respiratory mechanics data were recorded through a pressure sensor (Validyne ${ }^{\circledR}$, model DP45 - 24) connected to a software specifically developed for respiratory mechanical analysis (LabVIEW 5.1 ${ }^{\circledR}$, National Instruments, Austin, USA and R. A. Eletro Sistemas LTDA, Campinas, Brazil). The tidalvolume was evaluated through the integration of the flow and time signals obtained from a pneumotacograph (Model 8431 series - Hans Rudolph ${ }^{\circledR}$ Inc., Kansas City, USA) also connected to a pressure sensor (Validyne ${ }^{\circledR}$, model DP45 14), and using the same software for data acquisition. Ventilatory pressure was considered to be the difference between the PIP and the PEEP, and the dynamic compliance $\left(\mathrm{mL} / \mathrm{cm} \mathrm{H}_{2} \mathrm{O} \cdot \mathrm{kg}\right)$ was calculated by dividing $\mathrm{V}_{\mathrm{t}}(\mathrm{mL} /$ $\mathrm{kg}$ ) by VP ( $\left.\mathrm{cm} \mathrm{H}_{2} \mathrm{O}\right)$. The PIP adjustment was performed as necessary in order to maintain the target $\mathrm{V}_{\mathrm{t}}$ of $8 \mathrm{ml} / \mathrm{kg}$ for 30 seconds before every measurement.

\section{Pressure-Volume Curve}

After 15 minutes of ventilation, the animals received deep sedation with intraperitoneal sodium pentobarbital (25 $\mathrm{mg} / \mathrm{kg}$ ), followed by tracheal clamping for 5 minutes. Animals were immediately sacrificed with an intrathecal injection of $0.5 \mathrm{~mL}$ of lidocaine at $2 \%$, and the P-V curve was obtained by measuring the lung volume 30 seconds after insufflation, using increments of $5 \mathrm{~cm} \mathrm{H}_{2} \mathrm{O}$ until a maximum pressure of $30 \mathrm{~cm} \mathrm{H_{2 }} \mathrm{O}$ was attained; this was followed by the deflation of the lung by decrements of $5 \mathrm{~cm}$ $\mathrm{H}_{2} \mathrm{O}$ to $0 \mathrm{~cm} \mathrm{H}_{2} \mathrm{O}$.

\section{Statistical analysis}

The statistical analysis of the stability assay data was performed by Student $t$ test for parametric data, and by Mann-Whitney test for nonparametric data considering $P$ $<0.05$ to be the level of statistical significance.

\section{RESULTS}

\section{Immunogenicity assay}

The presence of antibodies against Butantan surfactant, Survanta, and Curosurf was evaluated in the sera of the animals at several dilutions and time points. Antibody response profiles were similar in all groups and time points. Therefore, we only present the results obtained at the 1:100 dilution (Figure 1). There were no significant statistical differences in antibody titers among the studied groups. None of the surfactants analyzed triggered antibody immune responses against their components in these animals.

\section{Stability assay}

Ninety-four New Zealand White premature rabbits were delivered; the recorded weights of the animals assigned to the Butantan surfactant and to the Curosurf groups were $29.9 \pm 2.6 \mathrm{~g}$ and $29.9 \pm 2.9 \mathrm{~g}$ (mean $\pm \mathrm{SD})$, respectively.

Respiratory mechanics ie, tidal volume (VT), dynamic compliance, ventilatory pressure, and pressure-volume curve are shown in Figures 2, 3, 4, 5, 6, and 7. It can be seen that the Butantan surfactant and Curosurf maintained similar effectiveness throughout the adverse storage conditions. Similar efficacy was demonstrated by the dynamic compliance, ventilatory pressure, and pressure-volume curve results. 

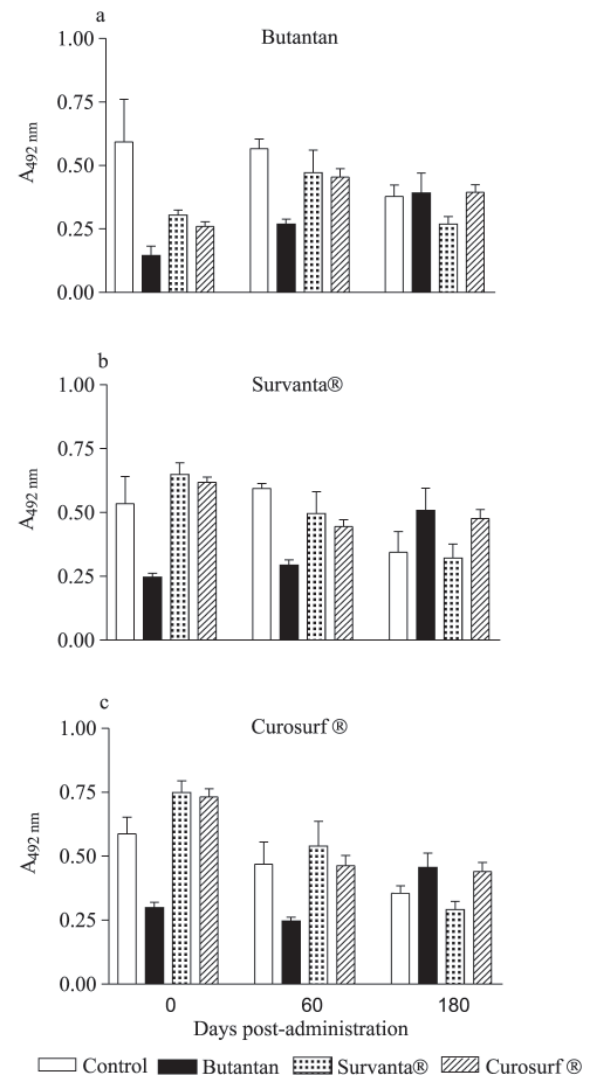

Figure 1 - Antibody levels against (a) Butantan, (b) Survanta, and (c) Curosurf surfactant proteins in the sera of rabbits after intratracheal administration. Bars represent mean absorbance \pm SD obtained for a 1:100 dilution of the sera. Data were analyzed by one-way analysis of variance (ANOVA) and Tukey's multiple comparison test considering $P<0.05$ (GraphPad Prism, 2.0, 1995).

\section{DISCUSSION}

Antibody levels detected after surfactant administration were not statistically different from levels detected before administration. It has been demonstrated that in neonatal respiratory distress syndrome, there is an increase in the pulmonary capillary permeability, causing a release of surfactant proteins into the circulation that could induce an immune response. ${ }^{11}$ Based on our results, we speculate that during lung development, surfactant proteins could also be released into the circulation eliciting a transitory immune response. This could explain the basal levels observed in our experiments in all groups.

According to the Brazilian Federal Health Agency, ANVISA, ${ }^{9}$ and in agreement with international guidelines, all new drugs must be analyzed concerning stability before usage in a clinical setting.

Stability tests describe drug behavior when submitted to adverse environmental conditions. Among environmental factors, such as temperature, moisture, and light, we studied how the Butantan surfactant responded to differ-
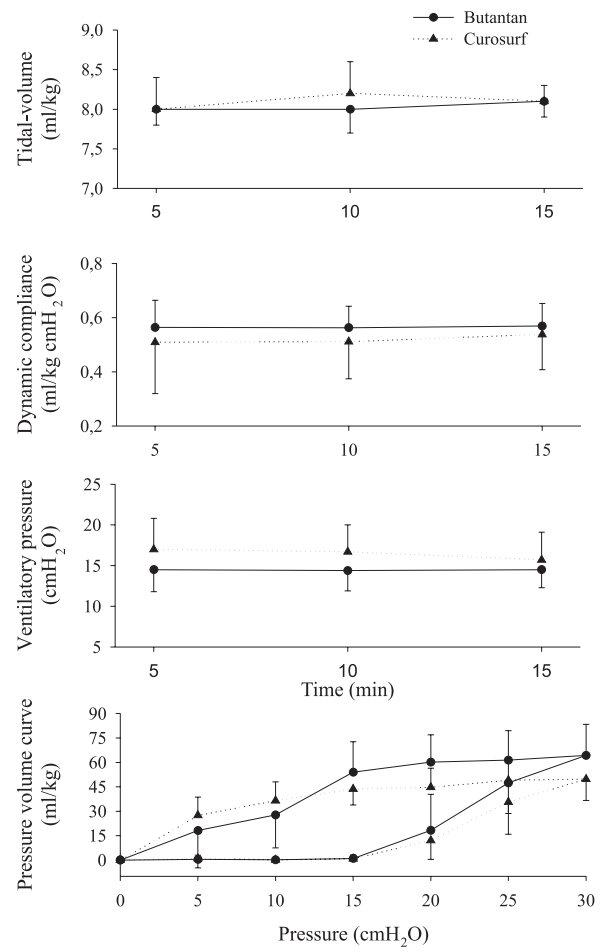

Figure 2 - Time point 0 (immediately after removal from the refrigerator and being warmed to $37^{\circ} \mathrm{C}$ for 5 minutes) data for tidal-volume (V), dynamic compliance (DC), ventilatory pressure (VP), and pressure-volume curve (mean $\pm \mathrm{SD}$ ). Data were analyzed by the Student $t$ test (parametric data) or Mann-Whitney test (nonparametric data).
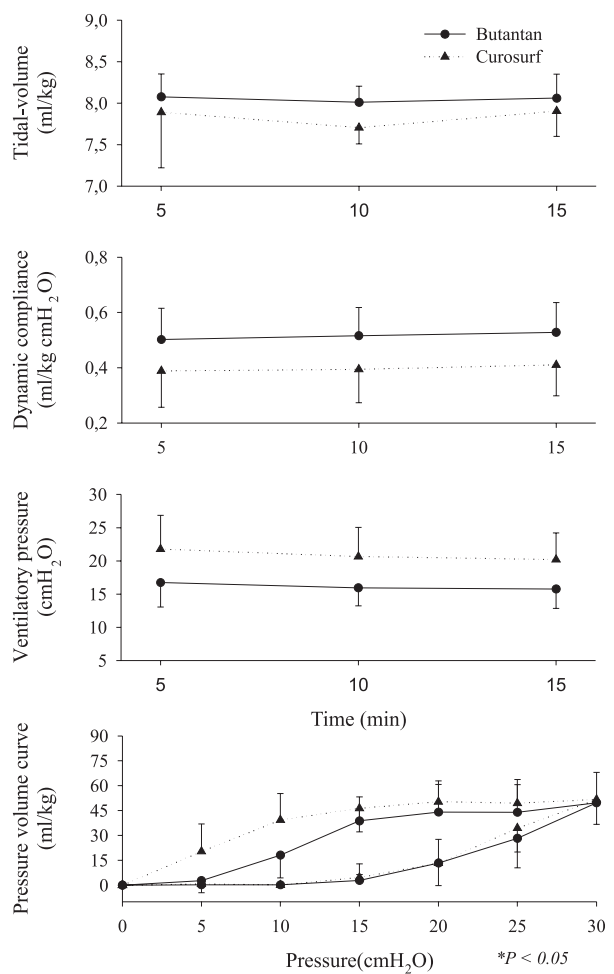

Figure 3 - Time point 1 (24 hours after removal from refrigerator and kept at room temperature $\left(24^{\circ} \mathrm{C}\right)$ before being warmed to $37^{\circ} \mathrm{C}$ for 5 minutes): data for tidal-volume $\left(\mathrm{V}_{\mathrm{t}}\right)$, dynamic compliance (DC), ventilatory pressure (VP), and pressure-volume curve (mean $\pm \mathrm{SD}$ ) were analyzed by the Student $t$ test (parametric data) or Mann-Whitney test (non-parametric data). 

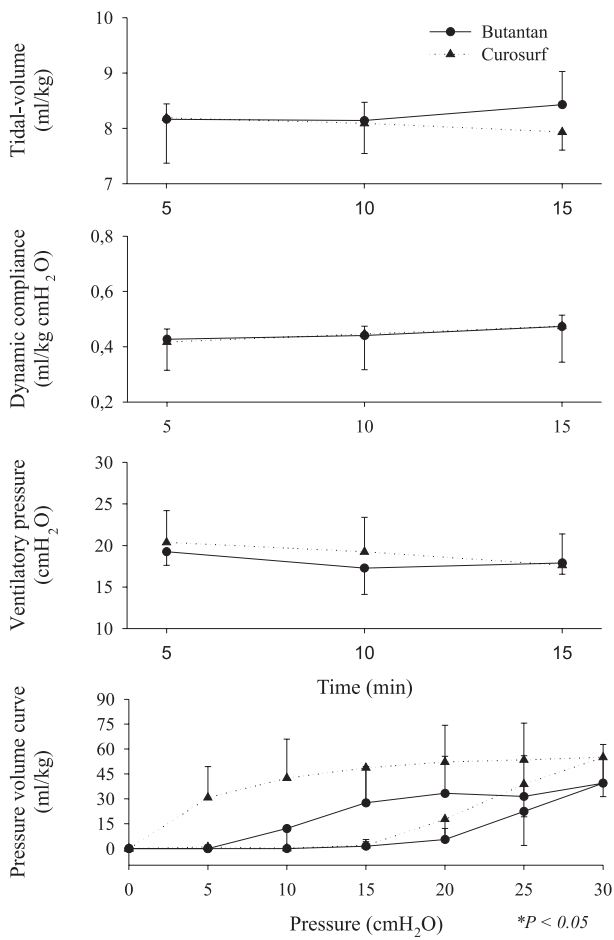

Figure 4 - Time point 2 (30 days after being kept at $20^{\circ} \mathrm{C}$-water bath temperature before being warmed to $37^{\circ} \mathrm{C}$ for 5 minutes) data for tidalvolume $\left(\mathrm{V}_{\mathrm{t}}\right)$, dynamic compliance (DC), ventilatory pressure (VP), and pressure-volume curve (mean $\pm \mathrm{SD}$ ). Data were analyzed by the Student $t$ test (parametric data) or Mann-Whitney test (nonparametric data).
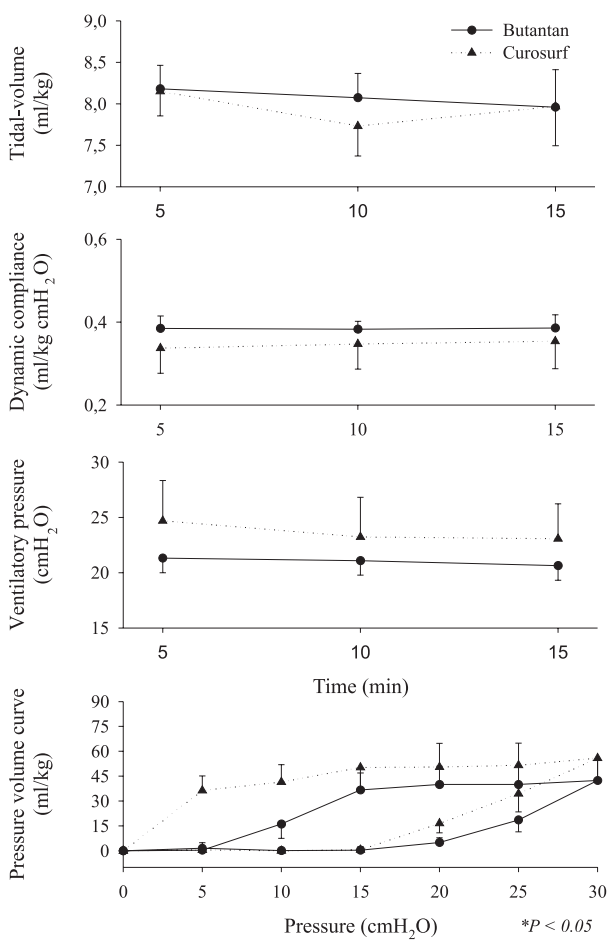

Figure 5 - Time point 3 (60 days after being kept at $20^{\circ} \mathrm{C}$-water bath temperature before being warmed to $37^{\circ} \mathrm{C}$ for 5 minutes) data for tidalvolume $\left(\mathrm{V}_{\mathrm{t}}\right)$, dynamic compliance (DC), ventilatory pressure (VP), and pressure-volume curve (mean $\pm \mathrm{SD}$ ). Data were analyzed by the Student $t$ test (parametric data) or Mann-Whitney test (nonparametric data).
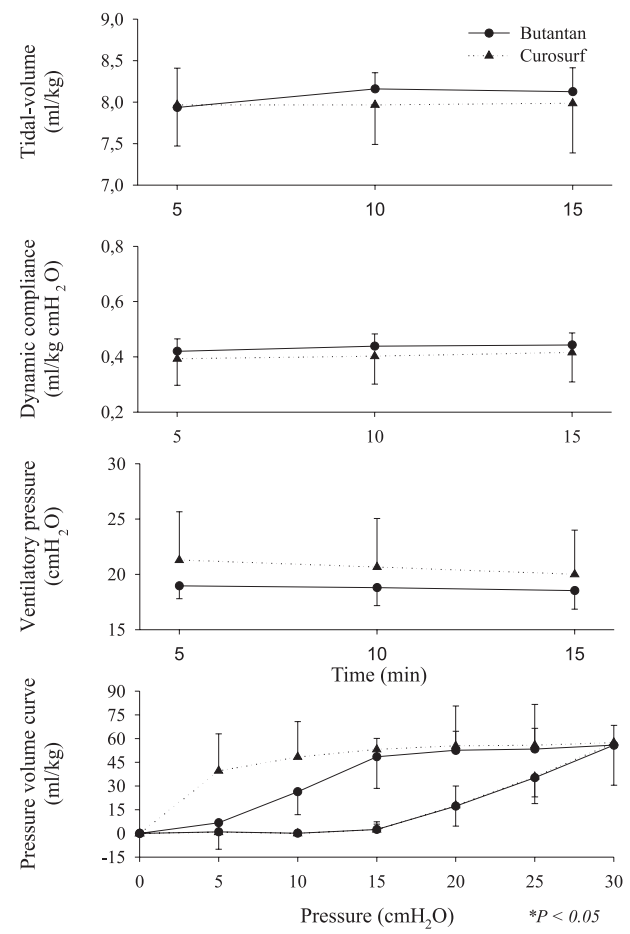

Figure 6 - Time point 4 (90 days after being kept at $20^{\circ} \mathrm{C}$-water bath temperature before being warmed to $37^{\circ} \mathrm{C}$ for 5 minutes) data for tidalvolume $\left(\mathrm{V}_{\mathrm{t}}\right)$, dynamic compliance $(\mathrm{DC})$, ventilatory pressure $(\mathrm{VP})$, and pressure-volume curve (mean $\pm \mathrm{SD}$ ). Data were analyzed by the Student $t$ test (parametric data) or Mann-Whitney test (nonparametric data).
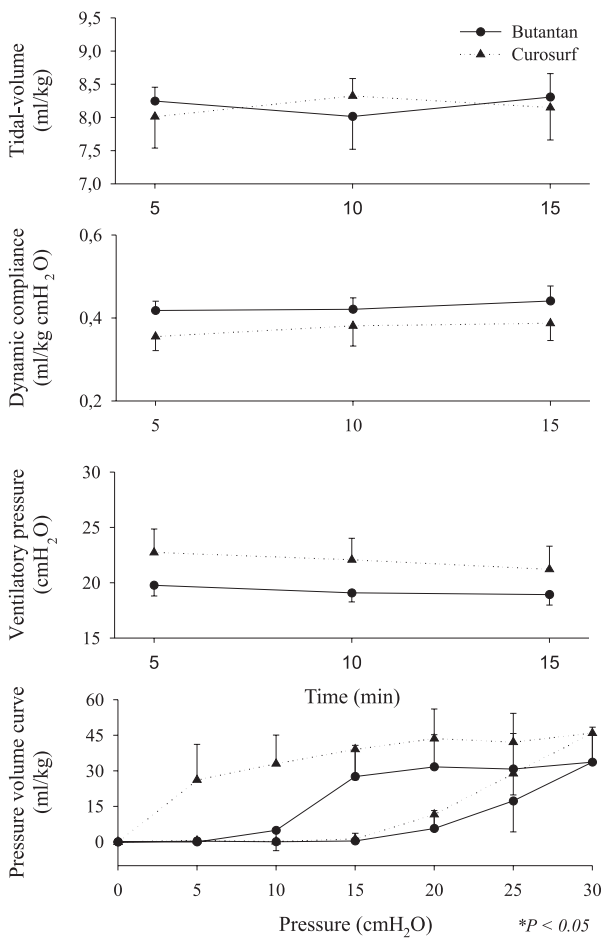

Figure 7 - Time point 5 (180 days after being kept at $20^{\circ} \mathrm{C}$-water bath temperature before being warmed to $37^{\circ} \mathrm{C}$ for 5 minutes) data for tidalvolume $\left(\mathrm{V}_{\mathrm{t}}\right)$, dynamic compliance (DC), ventilatory pressure (VP), and pressure-volume curve (mean $\pm \mathrm{SD})$. Data were analyzed by the Student $t$ test (parametric data) or Mann-Whitney test (nonparametric data). 
ent storage temperatures over time. We performed the studies with a premature rabbit model developed in our laboratory, which has been shown to be ideal for testing the efficacy of exogenous surfactant for treating premature rabbits with respiratory distress syndrome (SDR). Our results demonstrated that the Butantan surfactant was as effective as Curosurf even when submitted to adverse storage conditions over time. This can be seen in all time points studied, including time point 5 , for which the surfactants were kept in a water bath at $20^{\circ} \mathrm{C}$ for 180 daysThe similar efficacy between Butantan surfactant and Curosurf was dem- onstrated by the dynamic compliance, ventilatory pressure, and pressure-volume curve results.

In conclusion, the results of our study are relevant not only from the clinical point of view concerning the efficacy and safety of Butantan surfactant, but also for economical reasons, since Butantan surfactant may be a suitable as an alternative replacement therapy.

\section{ACKNOWLEDGMENTS}

This work was supported by Fundação Butantan.

\section{RESUMO}

Precioso AR, Sakae PPO, Mascaretti RS, Kubrusly FS, Gebara VCBC, Iourtov D et al. Análise da imunogenicidade e da estabilidade do surfactante pulmonar de origem porcina administrado em coelhos. Clinics. 2006;61(2):15360.

OBJETIVO: Estudar a imunogenicidade e a estabilidade do surfactante de origem porcina produzido pelo Instituto Butantan.

Método: Experimento imunogenicidade: 16 coelhos da raça New-Zealand-White (Peso de 1000g) foram divididos em grupos de 4 animais. Cada grupo foi designado para receber: a) Surfactante do Butantan, b) Survanta ${ }^{\circledR}$ (Abbott
Laboratories), c) Curosurf (Farmalab Chiesi) e d) nenhum tratamento com surfactante. Os surfactantes foram administrados via intratraqueal e o sangue dos animais foi coletado antes, 60 e 180 dias após a administração do surfactante. O soro obtido foi analisado quanto a presença de anticorpos anti-surfactante pelo método ELISA (enzyme-linked immunosorbent assay). Experimento estabilidade: O surfactante do Butantan usado neste experimento tinha sido armazenado por um ano em refrigerador (4 a $8^{\circ} \mathrm{C}$ ) e sua estabilidade foi analisada em condições distintas de experimentação, usando o modelo de coelho prematuro.

RESULTADOS: Experimento imunogenicidade: Nenhum 
dos surfactantes analisados determinou a produção de anticorpos contra seus constituintes. Experimento estabilidade: Os resultados deste estudo demonstraram que o surfactante do Instituto Butantan mostrou eficácia semelhante a do Curosurf após ter sido submetido à condições adversas ao longo do tempo. A eficácia foi demonstrada através da complacência pulmonar dinâmica, pressão ventilatória e da curva pressão-volume.

CONCLUSÃO: Os resultados deste estudo demonstraram que o surfactante do Instituto Butantan pode representar um tratamento alternativo de reposição de surfactante.

UNITERMOS: Surfactante pulmonar porcino. Imunogenicidade. Estabilidade.Modelo animal.

\section{REFERENCES}

1. Kubrusly FS, Netto SL, Iourtov D, Raw I, Araújo PS. Araújo A natural surfactant from pig lungs. Biotechnol Lett. 2000;22:1251-3.

2. Cianciarullo AM, Leme E, Beçak W, Raw I, Kubrusly FS. Ultrastructural chemical reaction to detect saturated phospholipids of a natural surfactant from pig lungs. Biotechnol Lett. 2001;23:1293-6.

3. Arcas RM, Chang CY, Proença RSM, Reyes AMA, Lyra JC, Gibelli MAC, et al. In vivo testing of a low cost surfactant compared to Survanta using the preterm rabbit model: lung mechanics and morphometric analysis. Pediatr Research. 2000;47:386A.

4. Chida S, Phelps DS, Soll RF, Taeusch HW. Surfactant proteins and antisurfactant antibodies in sera from infants with respiratory distress syndrome with and without surfactant treatment. Pediatrics. 1991;88:849.
5. Strayer DS, Hallman M, Merrit TA. Immnunogenicity of surfactant. II. Porcine and bovine surfactants. Clin. Exp. Immunol. 1991;83:41-6.

6. Whitsett JA, Hull WM, Luse S. Failure to detct surfactant protein-specific antibodies in sera of premature infants treated with Survanta, a modified bovine surfactant. Pediatrics. 1991; 87:505-10.

7. Strayer DS, Merrit TA, Lwebuga-Mukasa J, Hallman M. Surfactantanti-surfactant immune complexes in infants with respiratory distress syndrome. Am J Pathol. 1986;122:353-62.

8. Bartmann P, Bamberger U, Pohlandt F, Gortner L. Immunogenicity and immunomodulatory activity of bovine surfactant. Acta Paediatr. 1992;81:383-8. 
9. ANVISA Agência Nacional de Vigilância Sanitária. Resolução RE no 560. 2002.

10. Sun B, Kobayashi T, Curstedt T, Grossmann G, Robertson B. Application of a new ventilator-multi-plethysmograph system for testing efficacy of surfactant replacement in newborn rabbits. Eur Respir J. 1991;4:36470.
11. Jeffries AL, Coates G, O'Brodovich H. Pulmonary epithelial permeability in hyaline-membrane disease. N Engl J Med. 1984;311:1075-80. 